\section{Bioetanol Nira Lontar: Green Energy Alternatif Masa Depan}

\author{
Zakia Asrifah Ramly \\ Muhammad Akbar \\ Muhammad Ikhbar Ihsan \\ Arsad Bahri
}

\begin{abstract}
Abstrak. Meningkatnya jumlah penduduk dunia akan membuat kebutuhan energi negara-negara di dunia meningkat termasuk Indonesia. Ketersediaan minyak bumi Indonesia semakin menipis sehingga untuk memenuhi kebutuhan minyak dalam negeri. Indonesia harus import minyak dari negara lain. Hal ini perlu adanya energi baru dan terbarukan yang mampu memenuhi kebutuhan energi dalam negeri. Salah satu energi baru tersebut yaitu bioetanol. Bioetanol merupakan penyebutan alkohol atau etanol yang bersumber dari bahan hayati, salah satunya adalah nira siwalan. Artikel ini memberikan ulasan tentang bahan bakar alternatif dari fermentasi nira lontar. Penelitian ini menggunakan metode pendekatan data sekunder sebagai sumber datanya. Adapun hasil dari telaah pustaka yang dilakukan menunjukkan bahwa, tingginya kandungan gula pada nira lontar yang berkisar antara 10-30\% menjadikannya potensial untuk dikembangkan menjadi bioetanol. Namun, studi lebih lanjut harus dilakukan untuk menentukan efektivitas dan efisiensi penggunaan bahan bakar dari nira lontar pada mesin-mesin kendaraan.
\end{abstract}

Kata Kunci: Bioetanol, Nira Lontar, Bahan Bakar Alternatif, Energi Terbarukan

\section{Pendahuluan}

Kelangkaan bahan bakar minyak yang terjadi belakangan ini telah memberikan dampak yang sangat luas di berbagai sektor kehidupan. Sektor yang paling cepat terkena dampaknya adalah sektor transportasi. Fluktuasi suplai dan harga minyak bumi seharusnya membuat kita sadar bahwa jumlah cadangan minyak yang ada di bumi semakin menipis. Sebenarnya di Indonesia terdapat berbagai sumber energi terbarukan yang melimpah, seperti biodiesel dari tanaman jarak pagar, kelapa sawit maupun kedelai. Atau methanol dan ethanol dari biomassa, tebu, jagung dan lain-lain yang bisa dipergunakan sebagai pengganti bensin (Alkusma dkk, 2016). Total produksi energi primer yang terdiri dari minyak bumi, gas bumi, batubara, dan energi terbarukan mencapai 411,6 MTOE. Sebesar 64\% atau261,4 MTOE dari total produksi tersebut diekspor terutama batubara dan LNG (Hakim, 2020, Harefa, 2019). Selain itu, Indonesia juga melakukan impor energi terutama minyak mentah danproduk BBM sebesar 43,2 MTOE serta sejumlah kecil batubara kalori tinggi yangdiperlukan untuk memenuhi kebutuhan sektor industri. Total konsumsi energi final (tanpa biomasa tradisional) tahun 2018 sekitar 114MTOE dari sektor transportasi $40 \%$, kemudian industri 36\%, rumah tangga

\section{BIONATURE}

p-ISSN 1411 - 4720

e-ISSN 2654 - 5160

Abstract. The increasing number of world population will increase the energy needs of countries in the world, including Indonesia. The availability of Indonesian petroleum is running low so as to meet domestic oil needs. Indonesia must import oil from other countries.

This requires new and renewable energy capable of meeting domestic energy needs. One of the new energies is bioethanol. Bioethanol is the mention of alcohol or ethanol which comes from biological materials, one of which is siwalan juice. This article provides an overview of alternative fuels for palm sap fermentation. This study uses a secondary data approach as the data source. The results of the literature review showed that the high sugar content in palm sap, which ranges from 10-30\%, makes it potential to be developed into bioethanol. If sap is used as a bioethanol material, the selling value will increase. However, further studies must be carried out to determine the effectiveness and efficiency of using fuel from palm oil in vehicle engines. Keywords: Bioethanol, Nira Lontar, Alternative Fuels, Green Energy

Zakia Asrifah Ramly Universitas Negeri Makassar Indonesia

Muhammad Akbar

Universitas Negeri Makassar Indonesia

Muhammad Ikhbar Ihsan Universitas Negeri Makassar Indonesia

Arsad Bahri

Universitas Negeri Makassar Indonesia 
$16 \%$, komersial dan sektor lainnya masing-masing 6\% dan 2\%. Konsumsi BBM Indonesia dari tahun 2000 sampai 2018 cenderung mengalami tren kenaikan, sementaraproduksi minyak bumi Indonesia cenderungmengalami tren penurunan (Muziansyah, 2015).

Peningkatan jumlah penggunaan bahan bakar minyak ini terjadi jugadisebabkan oleh semakin meningkatnya penggunaan kendaraan bermotor diIndonesia dari tahun ketahun. Pada tahun 2016 jumlah kendaraan bermotorsebesar 128.503 .267 kendaraan meningkat 5,86\% dari tahun 2015 yangsebesar 121.394.185 kendaraan (Swaraz et al., 2019). Meningkatnya jumlah penggunaan kendaraan ini juga berakibat ke semakin tingginya pencemaranudara yang dapat mengakibatkan efek gas rumah kaca. Totalemisi gas rumah kaca Indonesia telah mencapai 1.808 juta CO2e, dimanasektor pertanian, kehutanan dan penggunaan lahan lainnya berkontribusisebesar $60,44 \%$ diikuti sektor energi dan transportasi sebesar 31,93\%, sektorlimbah sebesar $5,44 \%$ dan sektor industri dan penggunaan produk sebesar2,20\% (Emiroglu dan Sen, 2018, Bahri, 2018).

Hingga saat ini, terdapat lebih dari 64 negara yang telah menerapkan jalur penggunaan bahan bakar etanol sebagai bahan bakar kendaraan di dunia. Pada 2015, semua negara di dunia telah menghasilkan total 115,6 miliar liter etanol, dimana Amerika Serikat menyumbang lebih dari 50\% dengan 66,6 miliar liter. Sebelumnya, pada 2014, seluruh negara di dunia telah mengonsumsi total sekitar 100 miliar liter etanol, dimana sekitar 87\% digunakan sebagai bahan bakar (Hoang et al., 2017).

Etanol dapat digunakan sebagai campuran bahan bakar pada kendaraan bermotor karena etanol mampu meningkatkan angka oktan dan meningkatkan emisi dari kendaraan. Hal serupa pernah dilakukan oleh Harlin dan Sjofi'i (2017), hasil penelitian berupa efisiensi bahan bakar dengan penambahan etanol meningkat, dengan sifat dari etanol yang mudah menguap sehingga pembilasan pada ruang pembakaran membaik dan hasil yang menonjol dari sini pengurangan CO yang berkurang sampai $35 \%$. Serta pengujian emisi pada kendaraan bermotor dengan penambahan 10, 20, $30 \%$ perlakuan pada motor diperoleh bahwa mesin dingin menurun dengan menggunakan bahan bakar etanoldibandingkan hanya menggunakan bahan bakar saja.

Penggunaan etanol sebagai bahan bakar altenatif, juga mampu mengurangi konsumsi bahan bakar hingga 13,42 \% dan meningkatkan termal efisiensi 14,67\% artinya menghemat pengguanaan bahan bakar dan mampu meningkatakan perporma dari kendaran (Paloboran et al., 2016, Santosh dan Kumar, 2020). Serta pada penelitian serupa dilakukan oleh Prasetyo (2018) penambahan 30\% etanol pada bahan bakar menunjukan hasil 7,47 HP dan 5,51 pada torsi Nm menunjukkan hasil yang baik. Penambahan 30\% etanol menunjukkan penggunaan lebih hemat dari penggunaan bahan bakar $100 \%$ dilihat dari jarak yang cukup jauh pada pengujian.

Sebagai bahan bakar, minyak bumi juga menyebabkan efek gas rumah kacaakibat adanya karbondioksida $\left(\mathrm{CO}_{2}\right)$, karbon monoksida (CO), nitrogenoksida (NO) dan hidrokarbon (HC) dari sisa pembakaran. Adapun berbagai macam bahan bakar alternatif yang dapat dipergunakan untuk menanggulangi permasalahan tersebut adalah gas alam, gas hidrogen, LPG (Liquefied Petroleum Gas), biodiesel, nitrogen cair dan bioetanol. Dari semua jenisbahan bakar alternatif tersebut salah satu yang dapat dimanfaatkan adalah bioetanol (Azhar et al., 2017, Swaraz et al., 2019). Pengenalan energi alternatif ini juga merupakan upaya untuk mengurangi penggunaan bahan bakar minyak di Indonesia. Oleh sebab itu, pemanfaatan bioetanol sebagai bahan bakar terbarukan sangat baik jika dilakukan karena bioetanol sendiri memiliki nilaioktan yang tinggi. Selain itu, bioetanol juga mampu mengurangi jumlah emisikarbon monoksida (CO), penurunan emisi Nitrogen Oksida (NO) serta hidrokarbon dibandingkan dengan bahan bakar bensin biasa, yangmemungkinkan peningkatan rasio kompresi dan meningkatkan efisiensi termal mesin (Thangavelu et al., 2016, Gibson et al., 2017, Rustiaty, 2018). 


\section{Tujuan Penelitian}

Adapun tujuan dari penelitian ini yaitu sebagai berikut:

1. Mengidentifikasi karakteristik kandungan etanol fermentasi nira lontar terhadap bahan bakar kendaraan bermotor

2. Mengetahui pengaruh penambahan nira lontar terhadap bahan bakar yang dihasilkan.

\section{Metode Penelitian}

Penelitian ini merupakan pengkajian suatu topik berdasarkan data (database) yang diperoleh dari hasil-hasil penelitian yang dipublikasi dari jurnal-jurnal beresensi. Hasil ini barupa naskah berlandaskan pola yang tersusun atas analisis dan diskusi. Pengkajian ini diperoleh pemahaman baru terhadap topik yang dibahas.

Adapun tahapan dari penelitian ini yaitu pada tahap awal menentukan sistematika serta tahapan-tahapan yang akan digunakan dalam penulisan narrative review. Kemudian memilih dan mengumpulkan artikel-artikel bereputasi nasional maupun internasional sesuai dengan tema penelitian, baik berupa artikel jurnal ilmiah maupun artikel konferensi (Proceedings). Dari beberapa literature yang didapatkan kemudian mengkaji artikel sesuai dengan tujuan dari penelitian dan mengumpukan data dari artikel yang telah dikaji kemudian mengidentifikasi, menilai dan menginterpretasikan data-data tersebut sesuai dengan topik penelitian.

\section{Hasil dan Pembahasan}

Bioetanol adalah bahan bakar yang ramah lingkungan dan merupakan salah satu bentuk energi terbaharui yang dapat diproduksi dari tumbuhan. Sebagai campuran premium pada motor bensin, bioethanol adalah sumber energi yang dapat diperbarui (Handayani, 2005, Junipitoyo, 2019, Susilo dkk, 2020).Bioetanol dengan kadar 95-99\% dapat dipakaisebagai bahan pengganti premium, sedangkan kadar $40 \%$ dapat dijadikan sebagaialternatif substitusi minyak tanah (Moede dkk, 2017, Widyastuti, 2019).

Senyawa alkohol mempunyai nama kimia etanol atau etil alkohol. Proses fermentasi yang menghasilkan alkohol pada umumnya menggunakan proses batch yang dilakukan secara anaerob, dimana proses fermentasi sering menggunakan mikroorganisme untuk mempercepat proses fermentasi tersebut. Berbagai mikroroganisme yang digunakan untuk membantu mempercepat proses fermentasi menghasilkan alkohol, antara lain Saccharomyces cereviceae, Pichia stipits dan lain sebagainya (Mardiyah, 2017, Hawa dkk, 2019, Pai et al., 2020). Reaksi kimia pembentukan etanol adalah sebagai berikut:

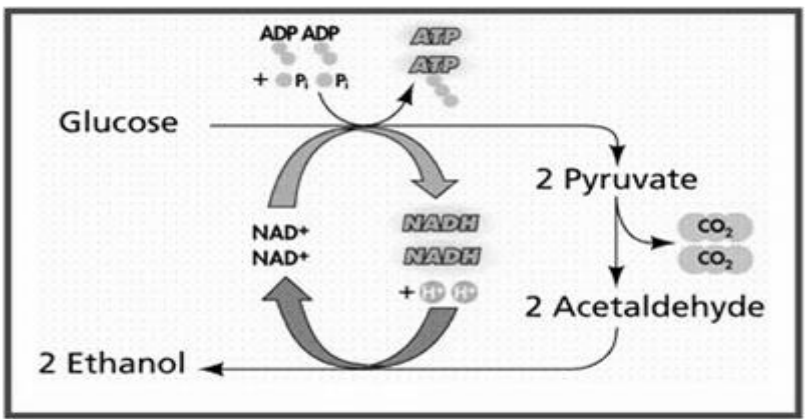

Gambar 1. Reaksi Kimia Metabolisme Etanol

(Sumber: Yuwono, 2005) 
Bioetanol mempunyai rumus molekul $\mathrm{C}_{2} \mathrm{H}_{5} \mathrm{OH}$ dengan rumus bangunnya $\mathrm{CH}_{3}-\mathrm{CH}_{2}-\mathrm{OH}$ namun sering ditulis dengan EtOH. Bioetanol diproduksi dari biomassa yang mengandung gula, pati dan selulosa (Hossain dan Jalil, 2017, Lee et al., 2017, Hakim, 2020 Susilo dkk, 2020). Untuk mengonversi selulosa atau pati menjadi glukosa pada prinsipnya dapat dilakukan dengan cara hidrolisis baik hidrolisis asam maupun dengan menggunakan enzim. Hidrolisis asam digunakan untuk bahan baku biomass seperti kayu yang mengandung selulosa dan lignin, sedangkan hidrolisis enzim digunakan untuk bahan yang mengandung pati. Glukosa yang dihasilkan selanjutnya difermentasi menggunakan ragi untuk menghasilkan etanol (Hossain dan Jalil, 2017). Menurut Rustiaty (2018) untuk meningkatkan kadar etanol adalah dengan mencapur aditif sulfit (NaSO) atau fosfat alkali (Na HPO + Na CO). Kemudian pada tingkat kemurnian etanol 99,5 sampai100\% digunakan untuk campuran bahan bakar. Berikut adalah rumus struktur dari bioetanol:

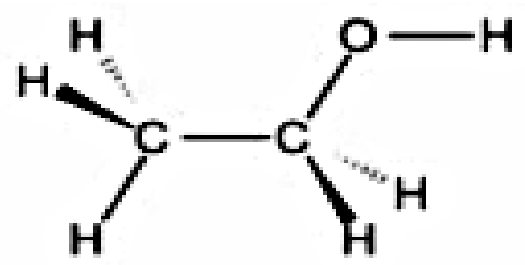

\section{Gambar 2. Struktur Molekul Bioetanol}

Lama fermentasi yang paling optimal untuk menghasilkan bioetanol menggunakan yeast Saccharomyces cereviseae adalah tiga hari. Jika waktu fermentasi dilakukan lebih dari tiga hari, kadar bioetanol yang dihasilkan semakin berkurang (Wijaya et al., 2018). Awalnya semakin lama waktu fermentasi, kadar bioetanol yang dihasilkan juga semakin tinggi, akan tetapi setelah kondisi optimum tercapai, kadar bioetanol yang didapatkan cenderung mengalami penurunan, hal ini disebabkan karena ketersediaan glukosa di dalam substrat sudah mulai sedikit. Selain itu juga terjadinya reaksi lanjut dari bioetanol sehingga bioetanol yang diperoleh menurun seiring bertambahnya waktu fermentasi. Reaksi lanjut ini disebabkan karena teroksidasinya bioetanol menjadi asam asetat. Dimana laju degradasi glukosa menjadi bioetanol lebih kecil dibandingkan laju oksidasi bioetanol menjadi asam asetat, sehingga kadar bioetanol yang dihasilkan semakin menurun (Maslanka et al., 2018, Germann et al., 2016).

Pemakaian bioetanol sebagai bahan bakar dapat dicampur dengan bensin dengan berbagai komposisi. Pemakaiannya memiliki kelebihan dan kekurangan. Menurut Amine dan Brakat (2019), Kelebihan pemakaian bioethanol adalah: 1) Bioetanol aman digunakan sebagai bahan bakar, titik nyala etanol tiga kali lebih tinggi dibandingkan bensin. 2) Emisi hidrokarbon lebih sedikit. Emisi gas buang kendaraan bermotor diukur dalam gram per kendaraan per km dari suatu perjalanan dan terkait dengan beberapa faktor seperti tipe kendaraan, umur kendaraan, ambang temperatur dan ketinggian. Kendaraan dengan usia dan jenis bahan bakar yang berbeda akan menghasilkan kadar emisi yang berbeda jugaKekurangan-kekurangan bioetanol dibandingkan bensin: 3) Pada mesin dingin lebih sulit melakukan starter bila menggunakan bioetanol. 4) Bioetanol bereaksi dengan logam seperti magnesium dan aluminium. Sebagai negara yang luas pertanian dan perkebunannya, Indonesia kaya dengan bahan baku untuk pembuatan bioetanol.

Etanol yang dihasilkan akan diccampurkan dengan gasoline dari kendaraan. Gasoline atau bahan bakar bensin merupakan senyawa hidrokarbon cair yang mudah menguap (volatile). Bensin sendiri terdiri dari senyawa parafine, naptalene, aromatic, dan olefin yang mana bersama-samadengan beberapa senyawa organik lainnya dan kontaminan. Adapunstruktur molekul dari bensin adalah C4 - C9 (Wang et al., 2015, Wiratmaja dan Elisa, 2020). Adapun karakteristik pentingdari bahan bakar hidrokarbon adalah volatilitas (penguapan), kandungan energi dan nilai 
oktannya. Salah satu bahan bakar minyak yang beredardiIndonesia adalah pertalite. Hasil penelitian dari Pratama dan Rizky (2020), pertalite memiliki nilai higher heating value (HHV)sebesar 47.500,12 kJ/kg dan lower heating value sebesar 44.260,12 kJ/kg.

Bahan bakar dari fermentasi nira lontar, dapat dipakai sebagai bahan bakar adiktif pada kenderaan bermotor dan mesin, misalnya bensin premium yang memiliki angka oktan 88 dicampur dengan etanol seperti pertamax, karena etanol memiliki nilai angka otan 117 (Junipitoyo, 2019., Wiratmaja dan Elisa, 2020). Perbandingan campuran etanol dan bensin premium adalah 1:9, dimana jika $100 \mathrm{ml}$ etanol dicampur dengan $900 \mathrm{ml}$ bensin premium menjadi $10.000 \mathrm{ml}$ bensin etanol, maka angka oktan menjadi $10 \%$ x $117+90 \%$ x 88 $=90,9$ atau mendekati pertamax (standar bahan bakar bensin yang digunakan di eropa) (Santosh dan Kumar, 2020).

Hasil penelitian yang dilakukan oleh Setyadi (2016), melaporkan bahwa penambahan bioetanol ke dalam bensin 88 merubah sifat fisika kimia bensin: Meningkatkan angka oktan bahan bakar bensin 88, terjadi penurunan sifat distilasi T.50, kandungan oksigen meningkat yang dapat menyebabkan peningkatan kecenderungan terbentuknya deposit di ruang bakar, stabilitas atau ketahanan bahan bakar terhadap oksidasi menurun. Pengaruh penambahan etanol terhadap kinerja bahan bakar: Tingkat emisi $\mathrm{CO}, \mathrm{CO}_{2}$, partikulat hidrokarbon, dan $\mathrm{NOx}$ menurun. Semakin tinggi persentase etanol maka tingkat penurunan emisi semakin bagus: Emisi $\mathrm{CO}_{2}$ turun sebesar 21,05 \%, Emisi CO turun sebesar 17,25 \%, Emisi HC turun sebesar $14,78 \%$, Emisi Nox turun sebesar 9,55\%.

Penelitian serupa dilakukan oleh Aryanto (2016) melaporkan bahwa pengaruh campuran bioetanol dari limbah blotong dengan premium terhadap kinerja dan emisi gas buang mesin dibandingkan dengan premium yang terbaikterdapat pada bahan bakar campuran E15 dengan torsi meningkat sebesar4,16\%, daya efektif meningkat sebesar 3,19\%, konsumsi bahan bakarmenurun sebesar 1,65\%, konsumsi bahan bakar spesifik menurun sebesar4,66\%. Pada putaran idle kadar CO menurun sebesar 1,54\% vol, kadarHC menurun sebesar 74,00 ppm, kadar CO2 meningkat sebesar 12,70\%vol dan kadar 02 menurun sebesar 4,03\% vol.

Penelitian lain yang dilakukan oleh Nofendri (2018) dalam penelitiannya tentang pengaruh penambahan aditif etanol pada bensin RON 88 dan RON 92 terhadap Prestasi Mesin. Adapun hasilpenelitian tersebut dijelaskan bahwa penambahan ethanol dalam premium dan pertamax dapat mempengaruhi sifat dari bahan bakar baik pada jenis pertamax maupun pada premium. Penambahan etanol. Penambahan sebanyak 5\% dapat meningkatkan prestasi mesin sebanyak $10.9 \%$ sedangkan penambahan $10 \%$ dapat meningkatkan efisiensi sebanyak $7 \%$ jika dibandingkan dengan bensin pertamax biasa pada semua putaran mesin.

Penelitian mengenai penggunaan bioetanol sebagai campuran bahan bakar terus dilakukan. Sutyadi (2016), mengemukakakn bahwa walaupun bioetanol mempunyai nilai oktan (octane rating) lebih tinggi dan emisi yang lebih bersih dibanding premium, namun etanol juga bersifat korosif dan membuat mesin lebih sulit di-starter. Sifat korosif ini menyebabkan perlunya material tahan korosif pada peralatan tertentu seperti, tanki bahan bakar, karburator, perpipaan, karet-karet penyekat dan lain-lain. Kendala saat starter masih sulit dihindari karena temperatur pembakaran sendiri/flash pointetanol tinggi sehingga pembakaran yang homogen akan sulit tercapai pada tekanan kompresi di ruang bakar, khususnya pada mobil lama yang menggunakan karburator konvensional. Oleh karena itu, penggunaan campuran bioetanol dalam bensin dibatasi antara 5-25\% agar kinerja mesin tidak terlalu berbeda.

\section{Kesimpulan}

Berdasarkan hasil review yang telah dilakukan maka dapat disimpulkan bahwa Penggunaan bioetanol sebagai campuran bahan bakar pertalite mampu meningkatkan torsi dan daya engkol motor bensin, serta memiliki potensi dalam menghemat konsumsi bahan bakar dan mereduksi emisi gas buang sisa pembakaran. Semakin bertambah ethanol pada pertalite, emisi 
karbonmonoksida dan HC mengalami penurunan. Bioetanol akan menjadi primadona bahan bakar yang ramah lingkungan atau Green Energy dimasa yang akan datang dan Indonesia dapat menjadi salah satu produsen bioetanol terbesar di dunia karena luasnya ketersediaan bahan baku. Pemanfaatan limbah sayur, buah, makanan, minuman dan lainnya sebagai bahan baku bioetanol dapat juga menjadi solusi untuk penanggulangan limbah yang akan merusak lingkungan. Untuk itu perlu lebih banyak penelitian pengembangan untuk bioetanol ini.

\section{Ucapan Terimakasih}

Ucapan terima kasih kepada Ayahanda Dr. Arsad Bahri, S.Pd, M.Pd selaku dosen pembimbing kegiatan ini atas segala dukungan baik dalam bentuk moril maupun materil. Selain itu, ucapan terima kasih kami kepada pihak Fakultas Matematika dan Ilmu Pengentahuan Alam (FMIPA) dan Universitas Negeri Makassar yang telah memfaslitasi dan mendukung kegiatan kami.

\section{Referensi}

Alkusma, YM, Hermawan \& Hardiyanto. (2016). Pengembangan Potensi Energi Alternatif dengan Pemanfaatan Limbah Cair Kelapa Sawit Sebagai Sumber Energi Baru Terbarukan di Kabupaten Kotawaringin Timur. Jurnal Ilmu Lingkungan. 14 (2): 96-102.

Amine, M \& Barakat, Y. (2019). Properties Of Gasoline-Ethanol-Methanol Ternary Fuel Blend Compared With Ethanol-Gasoline and Methanol-Gasoline Fuel Blends. Egyptian Journal of Petroleum. 28(4): 371-376.

Aryanto, D.I.K.A. (2016). Pengaruh Penggunaan Bioetanol dari Limbah Blotong Sebagai Campuran Premium terhadap Kinerja dan Emisi Gas Buang Mesin Honda Supra X 125. Jurnal Teknik Mesin. 4(3): 41-48.

Azhar, S.H.M., Abdulla, R., Jambo, S.A., Marbawi, H., Gansau, J.A., Faik, A.A.M., Rodrigues, K.F. (2017). Yeasts In Sustainable Bioethanol Production: A Review. Biochemistry and Biophysics Reports. 10(1): 52-61.

Bahri, N.A. (2018). Bumi dan Corporate Social Responsibility. Imanensi: Jurnal Ekonomi, Manajemen dan Akuntansi Islam. 3(1): 37-48.

Emiroglu, A.O \& Sen, M. (2018). Combustion, Performance and Emission Characteristics of Various Alcohol Blends In A Single Cylinder Diesel Engine. Fuel. 212, 34-40.

Germann, S.M., Baallal Jacobsen, S.A., Schneider, K., Harrison, S.J., Jensen, N.B., Chen, X., Stahlhut, S.G., Borodina, I., Luo, H., Zhu, J., Maury, J. (2016). Glucose-Based Microbial Production of The Hormone Melatonin In Yeast Saccharomyces cerevisiae. Biotechnology journal. 11(5), 717-724.

Gibson, L., Wilman, E.N \& Laurance, W.F. (2017). How Green is 'green'energy?. Trends in ecology \& evolution. 32 (12), 922-935.

Hakim, R.R. (2020). Model Energi Indonesia, Tinjauan Potensi Energi Terbarukan untuk Ketahanan Energi di Indonesia: Sebuah Ulasan.Jurnal Pengabdian Kepada Masyarakat, 1(1), 1-11. 
Handayani, S. (2005). Pemanfaatan Bioetanol Sebagai Bahan Bakar Pengganti Bensin. Fakultas Teknik Universitas Diponegoro. Semarang.

Harlin, H \& Sjofi'i, I. (2017). Pengaruh Pencampuran Etanol pada Pertalite terhadap Performa Motor Beat Fi 2016 Studi Pendidikan Teknik Mesin Fkip Universitas Sriwijaya. Jurnal Pendidikan Teknik Mesin. 4(1), 11-19.

Harefa, M. (2019). Hubungan Dana Bagi Hasil dengan Penerimaan Daerah dan Kemiskinan Provinsi Kalimantan Timur. Jurnal Ekonomi \& Kebijakan Publik. 9 (2), 147-160.

Hawa, LC., Mustofa, LM., Yusuf M. (2019). Studi Proses Termal dalam Pengolahan Nira Siwalan Menjadi Minuman Sinom Legen di PT. Petrokimia Gresik Jawa Timur. Jurnal Keteknikan Pertanian Tropis dan Biosistem. 7 (1), 20-27.

Hoang, A.T., Le, V.V., Dong, V.H., Tran, Q.V. (2017). Engine Performance and Emission Characteristics of In-Vietnam Motorcycles Using Biogasoline E10. Journal of Applied Sciences Research. 13(4), 18-26.

Hossain, N \& Jalil, R. (2017). Sugar and Bioethanol Production From Oil Palm Trunk (OPT). Asia Pacific Journal of Energy and Environment. 4 (1), 13-16.

Junipitoyo, B. (2019). Pengaruh Campuran Bioethanol pada Pertalite Terhadap Torsi dan Daya Piston Engine 1 Silinder. Jurnal Penelitian. 4 (3), 40-48.

Lee, Y.G., Jin, Y.S., Cha, Y.L., Seo, J.H. (2017). Bioethanol Production From Cellulosic Hydrolysates by Engineered Industrial Saccharomyces cerevisiae. Bioresource technology. 228, 355361.

Mardiyah, S. (2017). Pengaruh Lama Pemanasan Terhadap Kadar Alkohol pada Nira Siwalan (Borassus flabellifer). The Journal of Muhamadiyah Medical Laboratory Technologist. 2 (1), 9-15.

Maslanka, R., Kwolek-Mirek, M \& Zadrag-Tecza, R. (2018). Autofluorescence of Yeast Saccharomyces cerevisiae Cells Caused by Glucose Metabolism Products and Its Methodological Implications. Journal of microbiological methods. 146: 55-60.

Moede, F.H., Gonggo, S.T. and Ratman, R. (2017). Pengaruh Lama Waktu Fermentasi terhadap Kadar Bioetanol dari Pati Ubi Jalar Kuning (Ipomea batatas). Jurnal Akademika Kimia. 6(2): 86-91.

Muziansyah, D. (2015). Model Emisi Gas Buangan Kendaraan Bermotor Akibat Aktivitas Transportasi (Studi Kasus: Terminal Pasar Bawah Ramayana Kota Bandar Lampung). Jurnal Rekayasa Sipil dan Desain (JRSDD). 3(1), 57-70.

Nofendri, Y. (2018). Pengaruh Penambahan Aditif Etanol pada Bensin Ron 88 dan Ron 92 Terhadap Prestasi Mesin. Jurnal Konversi Energi dan Manufaktur UNJ. 5(1), 33-39.

Pai, A., Paul, P., Nayak, S., Singh, K.K., Narula, H. (2020). Potentiality of Saccharomyces Boulardii in Fermentation of Bio-Ethanol Derived from Fruit Wastes. Journal of Advanced Research in Fluid Mechanics and Thermal Sciences, 72 (72), 113-128. 
Paloboran, M.E., Sutantra, I.N., Sudarmanta, B., Sutantra, I.N., Sudarmanta, B. (2016). Performances and Emissions Characteristics of Three Main Types Composition of Gasoline-Ethanol Blended In Spark Ignition Engines. Mechanical Engginering. 10 (7), 552.

Pratama, A.W \& Rizky, S. (2020). Uji Karakteristik Laju Pembakaran dan Angka Oktan Bahan Bakar Polypropylene Cair Hasil Pemurnian Proses Distilasi Absorsi dengan Variasi Campuran Oktan Booster. Journal Mechanical and Manufacture Technology (JMMT). 1(1), $1-11$.

Rustiaty, B. (2018). Optimalisasi Sel Saccharomyces Cerevisiae untuk Meningkatkan Produktivitas dan Efisiensi Industri Etanol. Jurnal Teknologi \& Industri Hasil Pertanian. $23(2), 97$.

Santhosh, K \& Kumar, G.N. (2020). Effect Of 1-Pentanol Addition And EGR On The Combustion, Performance and Emission Characteristic of A CRDI Diesel Engine. Renewable Energy. $145,925-936$.

Sutyadi, P. (2016). Pengaruh Penggunaan Bioethanol sebagai Campuran Bahan Bakar pada Mesin Kendaraan Sepeda Motor 4 Langkah dengan Komposisi 10\%, 20\%, 30\%. Jurnal Konversi Energi dan Manufaktur UNJ. 3(1): 13-22.

Susilo, S.H., Suharono, M.F., Rarindo, H., Wicaksono, H. (2020). Analisa Campuran MetanolPertalite terhadap Kinerja dan Suhu Kerja Motor.Jurnal Energi dan Teknologi Manufaktur (JETM). 3(1), 27-34.

Swaraz, A.M., Satter, M.A., Rahman, M.M., Asad, M.A., Khan, I., Amin, M.Z. (2019). Bioethanol Production Potential In Bangladesh From Wild Date Palm (Phoenix Sylvestris Roxb.): An Experimental Proof. Industrial Crops and Products. 139, 507.

Thangavelu, S.K., Ahmed, A.S \& Ani, F.N. (2016). Review On Bioethanol As Alternative Fuel For Spark Ignition Engines. Renewable and Sustainable Energy Reviews 56, 820-835.

Yuwono, T. (2005). Biologi Molekuler. Erlangga. Jakarta.

Wang, X., Chen, Z., Ni, J., Liu, S. and Zhou, H. (2015). The Effects of Hydrous Ethanol Gasoline On Combustion And Emission Characteristics of A Port Injection Gasoline Engine. Case Studies in Thermal Engineering, 6 (1), 147-154.

Widyastuti, P. (2019). Pengolahan Limbah Kulit Singkong sebagai Bahan Bakar Bioetanol melaui Proses Fermentasi. Jurnal Kompetensi Teknik. 11(1), 41-46.

Wijaya, H., Sasaki, K., Kahar, P., Kawaguchi, H., Sazuka, T., Ogino, C., Prasetya, B., Kondo, A. (2018). Repeated Ethanol Fermentation From Membrane-Concentrated Sweet Sorghum Juice Using The Flocculating Yeast Saccharomyces Cerevisiae F118 Strain. Bioresource technology. 265, 542-547.

Wiratmaja, I.G \& Elisa, E. (2020). Kajian Peluang Pemanfaatan Bioetanol Sebagai Bahan Bakar Utama Kendaraan Masa Depan di Indonesia. Jurnal Pendidikan Teknik Mesin Undiksha. 8 (1), 1-8. 
56 Jurnal Bionature, Volume 21, Nomor 1, April 2020

Bioetanol Nira Lontar: Green Energy Alternatif Masa Depan

e-ISSN 2654-5160 p-ISSN 1411-4720 (hlm. 48-56)

\begin{tabular}{|c|c|}
\hline Zakia Asrifah Ramly & 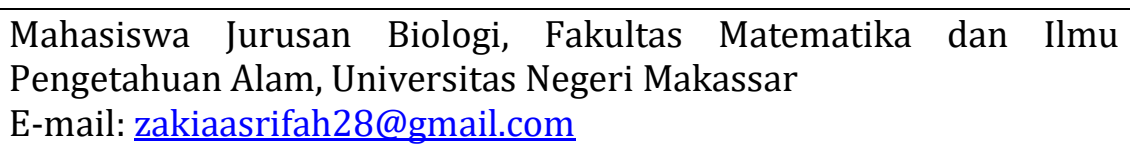 \\
\hline Muhammad Akbar & 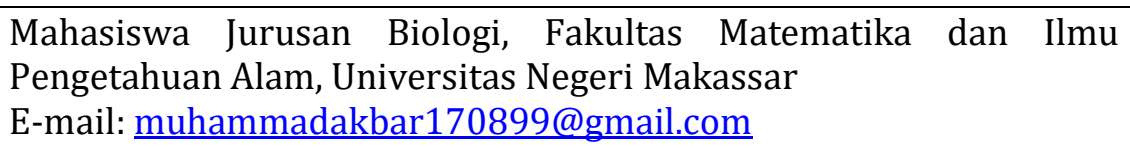 \\
\hline $\begin{array}{l}\text { Muhammad Ikhbar } \\
\text { Ihsan }\end{array}$ & 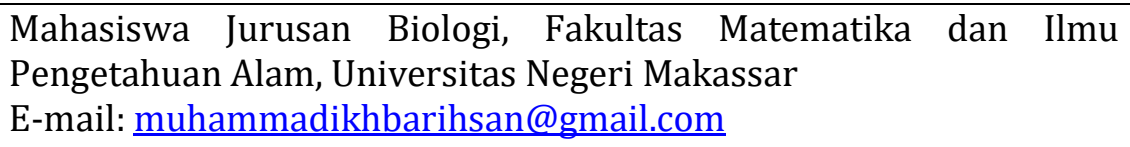 \\
\hline Arsad Bahri & $\begin{array}{l}\text { S.Pd, M.Pd, Dr. Dosen Jurusan Biologi, Fakultas Matematika dan } \\
\text { Ilmu Pengetahuan Alam, Universitas Negeri Makassar } \\
\text { E-mail: arsad.bahri@unm.ac.id }\end{array}$ \\
\hline
\end{tabular}

